\title{
LANGUAGE AND STYLE OF INTERNATIONAL AGREEMENTS OF WESSEX
}

\author{
Sergey V. Mukhin, Darya A. Efremova \\ Moscow State Institute of International Relations (University), \\ 76, Prospect Vernadskogo, Moscow, 119454, Russia.
}

\begin{abstract}
The article is concerned with a complex study of the specific features of international agreements in the aspect of functional stylistics and text linguistics. The linguistic evidence has been collected in the Old English texts of international agreements made in the late 9th century by the Wessex kings Alfred the Great, Eadward and the chief of Danes Guthrum as testified by the late 11th - early 12th century manuscript. The present article is intended to make some scientific contribution by trying to solve a number of functional style problems of a specific text type in diachrony, i. e. to consider linguostylistic features of international documents in the historical aspect. It has been found out that lexical, grammar, structuralsyntactic and compositional features of the text type in question emerged at the early stage of its existence and are still functional now. The research also proceeds to various language levels, in particular the textual one, to reveal and describe the specific features of Old English international treaties which are no longer inherent in modern formal papers of the same type. As a result of analyzing the linguistic evidence, a conclusion is made that there has been effected some linguostylistic change in the course of formation of the given text type, which, however, can hardly be desribed as drastic.
\end{abstract}

Key Words: linguostylistic features, text type, terminology, Wessex, functional stylistics, text linguistics, history of English, Old English

For citation: Mukhin S.V., Efremova D.A. 2020. Language and Style of International Agreements of Wessex. Philological Sciences at MGIMO. Vol. 6. No 4(24). P. 45-55. https://doi.org/10.24833/24102423-2020-4-24-45-55

\section{ЛИНГВОСТИЛИСТИЧЕСКИЕ ЧЕРТЫ МЕЖДУНАРОДНЫХ СОГЛАШЕНИЙ УЭССЕКСА}

\author{
С.В. Мухин, Д.А. Ефремова
}

Московский государственный институт международных отношений (университет) МИД России, 119454, Россия, Москва, пр. Вернадского, 76.

\begin{abstract}
Аннотация. Статья посвящена комплексному изучению особенностей международных соглашений с точки зрения функииональной стилистики и лингвистики текста. Материалом для исследования стали древнеанглийские тексты международных договоров, заключённых в коние IX в. королями Уэссекса Альфредом Великим, Эдуардом и правителем данов Гутрумом по ману-
\end{abstract}


скрипту кониа XI - начала ХII вв. Научная новизна статьи заключается в попьтке решить функционально-стилистические проблемы отдельно взятого типа текста в диахронном аспекте, то есть рассмотреть тингвостилистические черты международньх документов в историческом аспекте. В ходе исследования было установлено, что большинство лексико-грамматических, структурно-синтаксических и композиционных особенностей изучаемого типа текста появились на раннем этапе его развития и сохранились до наших дней. В статье также выделяются и описываются на всех уровнях языка, прежде всего текстовом, спеиифические черты древнеанглийских международных договоров, не характерные для современных офиииальноделовых документов того же типа. Оставляя за скобками лексико-грамматические изменения в английском языке в иелом, можно утверждать, что базовые параметры международных договоров в ходе своего формирования и развития как типа текста претерпели определённые лингвостилистические изменения, которье, однако, не являются кардинальньми.

Ключевые слова: лингвостистические черты, тип текста, терминология, Уэссекс, функциональная стилистика, лингвистика текста, история английского языка, древнеанглийский язык

Для цитирования: Мухин С.В., Ефремова Д.А. 2020. Лингвостилистические черты международных соглашений уэссекса. Филологические науки в МГИМО. Том 6. № 4(24). С. 45-55. https:// doi.org/10.24833/2410-2423-2020-4-24-45-55

\section{1. Введение}

$\mathrm{B}$ опрос о становлении функциональных стилей довольно актуален в современной лингвистической науке, поскольку его решение даёт важную информацию о том, по какому пути в своём развитии идут подсистемы языка, и позволяет предположить, какие изменения могут произойти в них в будущем. Проблема возникновения и эволюции официально-делового стиля интересовала функциональную стилистику ещё с 70-х годов XX в. [16; 8], однако исторические изменения типовых черт разновидностей текстов официально-делового стиля, в частности текстов международных документов, достаточного изучения не получили. Настоящее исследование ставит своей целью выявить лингвостилистические черты текстов международных соглашений древнеанглийского периода, сопоставить их с особенностями современных текстов этого типа для того, чтобы выяснить, какие из них сформировались уже на раннем этапе развития изучаемой разновидности текстов, а какие являются приобретением более поздних периодов.

Для достижения обозначенной цели анализируются тексты памятников древнеанглийской письменности: 1) договор между королём Уэссекса Альфредом Великим (Ælfred se 3reata, ок. 849 899 / 901 гг.) и королём даном Гутрумом (Зиðrum, в крещении Ательстан (Æpelstan), ? - 890 гг.); 2) краткое уложение законов, принятых договаривающимися сторонами совместно на территории Уэссекса и в области датского права после установления мира между скандинавами и англосаксами [30]. Приводимые примеры взяты из манускрипта конца XI - начала XII вв. Corpus Christi College Cambridge Manuscript 383 [23], представляющего собой раннюю версию рассматриваемых текстов, поскольку её язык носит архаичный характер [22].

В настоящем исследовании применялись как специфические стилистические методы (метод стилистической интерпретации текстов, семантико-стилистический анализ), так и универсальные методы языкознания (лингвистическое наблюдение и описание, сопоставительный метод и др.). В ходе исследования решается ряд практических задач: 1) изучение теоретической литературы для выделения лингвостилистических черт современных международных соглашений; 2) выявление лингвостилистической специфики древнеанглийских международных договоров; 3) определение того, какие из черт современных международных соглашений сложились уже в древнеанглийский период. 


\section{2. Лингвостилистические черты современных международных договоров.}

Поскольку рассматриваемые тексты представляют собой международный договор и свод международных законов, то анализ теоретических источников проводился с привлечением лингвистических исследований междунароно-правовых и юридических документов. В результате изучения работ по вопросу лингвостилистической специфики современных международных соглашений удалось выделить следующие черты данного типа текста:

- стандартизация композиции [25; 7];

- стереотипность лексико-грамматического оформления [11;17;26];

- однородность синтаксических структур (синтаксический паралеллизм преимущественно условно-уступительных периодов) [9; 12; 21];

- сложность синтаксических конструкций [3; 20;28];

- стремление к языковой экономии [13;18];

- связность на основе лексических повторов, вводных и союзных слов [13; 19];

- $\quad$ тенденция к безличным способам выражения $[2 ; 4,6]$.

\section{3. Лингвостилистичекая специфика текста международных договоров Уэссекса.}

Анализ текста рассматриваемых соглашений показывает, что многие лингвостилистические черты современных международных договоров обнаруживаются в текстах изучаемых документов: 1) стереотипность лексико-грамматического оформления: терминологичность, клишированность лексики; негативность; 2) стандартизация членения и композиции; 3) однородность синтаксических структур: синтаксический параллелизм условных периодов; 4) связность на основе лексических повторов, вводных и союзных слов; 5) тенденция к деперсонализованным способам изложения; 6) сложность синтаксических конструкций; 7) стремление к языковой экономии.

Рассмотрим последовательно конкретные лингвостилистические черты исследуемых текстов.

\subsection{1. Стереотипность лексико-грамматического оформления: использование специальной терминологии}

Терминологичность текста рассматриваемых соглашений является их наиболее ярко выраженной характеристикой, которая способствует стандартизации и спецификации текста документов. В целом, термины могут быть сгруппированы в зависимости от обслуживаемых ими сфер деятельности и лексической семантики самих единиц1:

- $\quad$ собственно дипломатические термины и лексика, употребимая в международной практике: frið (мир, мирный договор), wita (советник), деоd (народ), landzeтоег (граница), here (власть, суверенитет), wedd (гарантия), swutulunз (демонстрация намерений) и др.;

- общеюридические и процессуальные термины: laза (закон), ар (клятва, присяга), beteon (предвявлять обвинение), ladian (оправдывать), sprже (судебное дело), зyldan (выплачивать штраф, компенсацию и т.п.), зежугdап (причинять ущерб), зеtутап (поручитель), dom (указ, предписание), зегсеdnis (установление, уложение, закон), зоd (совершенствование, поправка), stеог (наказание) и др.;

- названия правонарушений, преступных действий и преступников: ofslean (yбивать), mansliht (убийство), зestalian (красть), зefeohtan (драться, причинять побои), forswerian (лжесвидетельствовать, совериать клятвопреступление), deapscyld (уголовное преступление), иtlah (находящийся вне закона, преступник), forwyrht (преступник), limlœwео (преступник, по приговору подвергшийся увечью) и др.;

- общественно-политическая и экономическая лексика: зinzra (подданный, вассал), ceorl (свободный человек низшего сословия), заfolland (выделенная в пользование земля, земельный надел),

\footnotetext{
1 Зд. и далее древнеанглийская орфография даётся в соответствии с отечественной учебно-исследовательской и издательской традицией - Авт.
} 
деош (раб, рабыня), бізе (торговля, обмен), жоruldlic (светский, секулярный), tеорипз (десятина), суріпз (сделка), feoh (имущество) и др.

\subsection{2. Стереотипность лексико-грамматического оформления: тенденция к клишированию}

Одной из характерных черт древнеанглийских юридических документов, в том числе международных, является широкое употребление штампов, клишированных выражений и оборотов с фразеоматически связанными значениями [10]. Использование подобных единиц служит целям формализации установлений закона и облегчению коммуникации в сфере дипломатических отношений. Обнаруженные в рассматриваемых текстах клише и штампы носят, в основном, адвербиальный или адъективный характер: oft \& unseldan (часто и постоянно), seolfe (таковой, вышеупомянутый), wordes одде шеогсе (словом или делом), зе for zeborene ze for unzeborene (отныне и впредь, букв: за рождённых и нерождённых), mid rihte (по праву) и др., в то время как фразеоматические единицы являются глагольными словосочетаниями: zercednis zeceosan (nринимать соглашение), адаs swarian (приносить клятвы), зеrсеdпіs зесжкљап (провозглашать договор), ladian durran (искать оправдания, заявлять о невиновности), deape зеfylan (забить насмерть) и др.

Все перечисленные единицы характеризуются воспроизводимостью в дипломатическом тексте, некоторой степенью семантической мотивированности и стёртой экспрессивностью. Единственным исключением среди обнаруженных связанных словосочетаний выступает образная единица с переосмысленным значением компонентов cløne bøe habban (быть в безопасности, иметь гарантию) - букв.: иметь чистую спину, употребляемая в следующем контексте:

3if ðonne zebyrize, poet for neode heora hwylc wið ure bize habban wille oððe we wið heora mid yrfe \& mid cehtum, ðat is to ðafianne on ða wisan, poet man zislas sylle friðe to wedde \& to swutulunze, poet man wite, poet man cloene boec hoebbe.

Если так случится, что кто-либо из них для своих нужд пожелает торговать с нами или мь с ними скотом и товаром, то это следует разрешать при условии, чтобы предоставлялись заложники как гарантия мира и свидетельство, чтобы было понятно, что не замышляется веротомство. ${ }^{2}$

В этом примере, наряду с использующимися здесь же фразеоматизмами, единица clone bøe habban не добавляет эмотивности тексту, а служит, скорее, для наиболее полной и ёмкой передачи установлений документа.

\subsection{3. Стереотипность лексико-грамматического оформления: использование негативности}

В условиях отсутствовавшего в Раннем Средневековье деления на отрасли права не существовало также и чёткого разграничения используемых методов регулирования. В рассматриваемых документах явно просматривается тенденция к применению императивно-запретительного метода, в настоящее время в основном присущего уголовному праву. Можно утверждать, что лексико-грамматическим средством вербализации запрета в тексте рассматриваемых документов выступает негативность, причём для древнеанглийского периода преобладающей нормой было полинегативное отрицание. Рассмотрим конкретные примеры:

\& $\boldsymbol{n} \boldsymbol{e}$ ðeowe ne freo ne moton in ðone here faran butan leafe, ne heora nan ðe ma to us.

ни рабы, ни свободные не должны переходить под власть данов без разрешения, и от них никто не может к нам.

В приведённом примере полинегативный тип отрицания обеспечивается основной отрицательной частицей древнеанглийского периода пе и отрицательным местоимением пап (никто, ни один).

ne dyde man nafre on Sunnandoezes freolse cenizne forwyrhtne

пусть не казнят никогда в воскресньй праздник преступника.

\footnotetext{
2 Зд. и далее перевод наш. - Авт.
} 
В данном примере отрицательное наречие næfre (никогда) помимо структурно-семантической функции обеспечения полинегативности выполняет также функцию эмфазы.

\section{2. Стандартизация композиции и членения текста}

В текстах рассматриваемых международных документов можно семантически выделить следующие композиционные единицы: преамбула и основная часть (содержание договора). Преамбула в договоре Альфреда и Гутрума выглядит следующим образом:

And pis is seo zercednis eac, pe Alfred cynz \& Zuðrum cynz \& eft Eadward cynz (\& Zuðrum cynz) zecuran \& zecwoedon, pa pa Enzle \& Dene to fripe \& to freondscipe fullice fenzon.

И это также законы (уложение), которые король Альфред и король Гутрум, а затем король Эдуард и король Гутрум издали и провозгласили, когда англосаксы и даны мир и дружбу всеиело приняли.

Приведённый пример полностью удовлетворяет определению преамбулы как вводной части международного договора, содержащей перечень договаривающихся сторон и лиц, их званий и должностей и указание мотивов, послуживших основанием для заключения договора [5].

В отличие от современных международных соглашений, в анализируемых текстах нет заключения, которое обычно содержит информацию об условиях вступления договора в силу, сроках действия, условиях и порядке расторжения и призвано бороться с тайной дипломатией. Очевидно, что такой практики в IX в. ещё не существовало, поэтому и отсутствует данная композиционная часть документа.

Письменная традиция Древней Англии также не знала деления текста на абзацы. Абзац как средство рубрикации, изначально обозначаемый знаком алинеи, а затем красной строкой, появился в Европе только в эпоху Высокого Средневековья. Соответственно, текст исследуемых договоров в оригинале написан единым массивом без какого-либо деления на главы и абзацы (см. рис. 1).

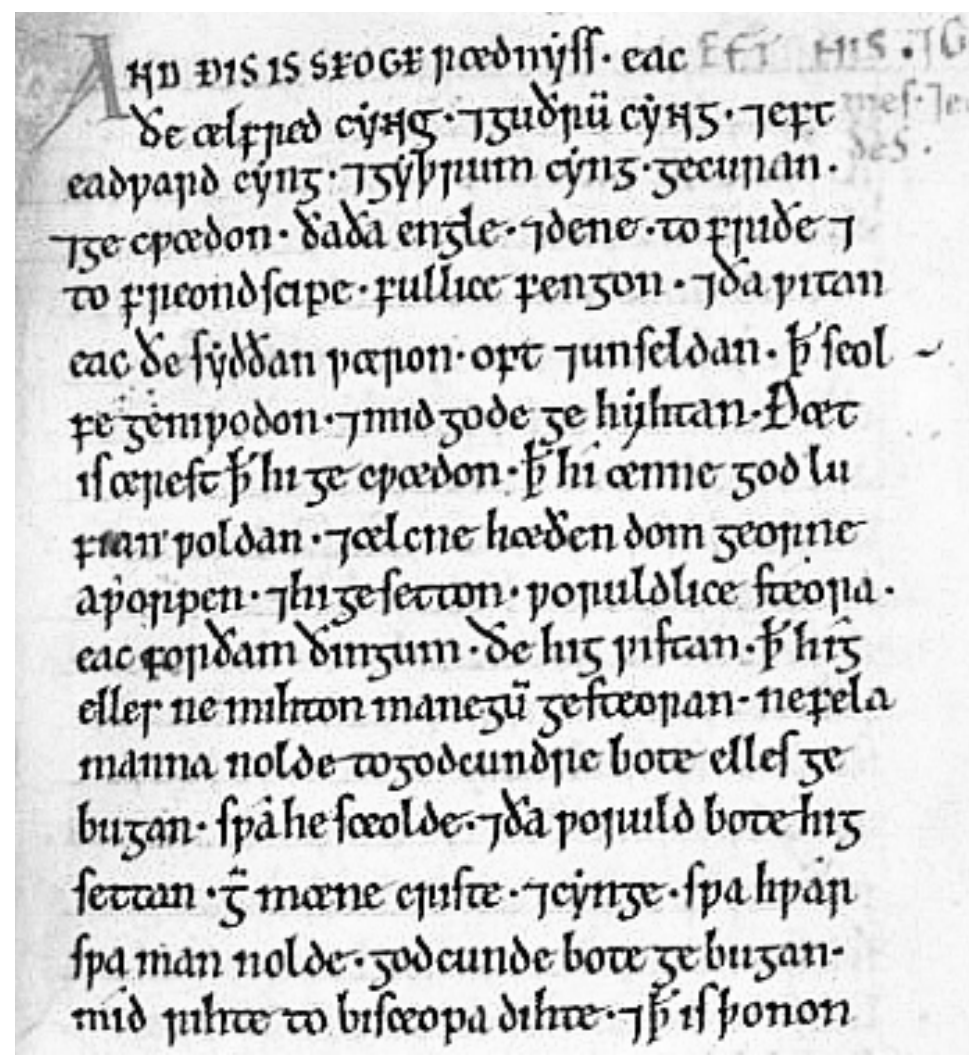

Рис. 1. Часть страницы из рукописи Corpus Christi College Cambridge Manuscript 383, folium $13 r$ с преамбулой и двумя первыми пунктами договора между королём Эдуардом и королём Гутрумом. 
Тем не менее, нельзя сказать, что категория членения текста совсем нехарактерна для международных договоров Уэссекса. Рубрикация исследуемых текстов осуществлялась особыми, главным образом лексическими, средствами. Так, можно отметить, что последовательные пункты договора могли выделяться посредством союза зif (если), вводящего условные придаточные. Употребление данного союза достаточно точно совпадает с современными средствами рубрикации, то есть красной строкой, параграфами, нумерацией. Каждый случай употребления условного предложения маркирует соответствующий параграф договора. Так рубрицирование соглашения Эдуарда и Гутрума выглядит в современной адаптации:

\$1. Zif hwa Romfeoh forhealde... (Если кто не выплатит динарий Святого Петра ...);

\$2. Zif hwa leohtzesceot ne zeloeste... (Если кто не предоставит свечную подать ...);

\$3. Zif hwa sulhoelmyssan nе sylle... (Если кто не выплатит подать с плуга ...);

$\$ 4$. Zif hwa onizra zodcundra zerihto forwyrne... (Если кто откажется от уплаты любых иерковных налогов .... $)^{3}$ и т.д.

\section{3 Однородность синтаксических структур:} синтаксический параллелизм условных периодов с сослагательным наклонением

Типичным синтаксическим признаком текста древнеанглийского юридического документа, в том числе международного соглашения, надо признать широкое использование условных периодов, что обусловлено логикой изложения правовых норм, описывающих условия, при которых должны наступить определённые законом последствия. Наиболее частотными лексико-грамматическими маркерами таких синтаксических конструкций являются союз зif (если) и синонимичные ему союзы, вводящие условные придаточные предложения, и глагольные формы сослагательного наклонения в главных и придаточных предложениях. Рассмотрим пример:

\& zif hwa Cristendom wyrde oððe hœependom weorpize wordes oððe weorces, zylde swa wer swa wite swa lahslitte, be pam pe syo doed sy.

И если кто оскорбит христианство или вознесёт язычество словом или делом, то пусть заплатит вергельд $\partial^{4}$ или шттраф или лахслит 5 по тому, каков есть проступок.

В данном сложноподчинённом предложении союз зif вводит условное придаточное. Поскольку действия, называемые глаголами в придаточном предложении, не рассматриваются как свершившийся или совершающийся факт, то в соответствии с общей грамматической нормой древнеанглийского языка, глаголы wyrdan (ранить, портить, причинять вред) и weorpian (ценить) принимают формы презенса сослагательного наклонения: wyrde и weorpize. То же справедливо в отношении второго придаточного условия: pe syo doed sy, где реализована форма презенса сослагательного наклонения глагола beon (быmb). В главном предложении форма презенса сослагательного наклонения глагола zyldan (выплачивать, возмещать) выражает оптативный характер действия, что, наряду с обозначением нереальности, было одной из двух главных функций сослагательного наклонения [15].

Условные предложения лежат в основе синтаксического параллелизма характерного для древнеанглийских международных договоров (см. примеры выше). Параллельность условных периодов обеспечивает единообразие построения текстов древнеанглийских международных документов и структурное постоянство состава информации.

\footnotetext{
3 Перечисляются различные виды церковных налогов: romfeoh - папская подать, leohtzsceot - подать на освещение, sulh-celmesse - подать с каждого плуга [24], а также zodcund zeriht - букв. «должное Господу» как гипероним, означающий всю совокупность церковных пошлин.

4 Werzeld - денежная компенсация, которую виновный выплачивал родственникам убитого им свободного человека [29]. У древнегерманских народов вергельд постепенно заменил кровную месть.

5 Lahslitte - существительное скандинавского происхождения, означавшее вид штрафа, назначавшегося в зависимости от общественного положения виновного [28].
} 


\section{4 Связность на основе лексических повторов, вводных и союзных слов}

Строгость логического построения является характерной чертой официально-деловых документов [25], в том числе и международно-правовых, поэтому все виды связности как когезия, так и когерентность играют в этих текстах большую роль.

Для обеспечения горизонтальной связности в древнеаглийских международных договорах используются идеографические синонимы или лексические повторы:

ne fela manna nolde to zodcundre bote elles zebuzan, swa hy sceolden \& pa woruldbote hiz zesetton zemone Criste \& cynze, swa hwar swa man nolde zodcunde bote zebuzan mid rihte to bisceopa dihte.

многие не захотели бы выплачивать церковные налоги, поэтому они установили мирские итрафные выплаты Христу (иеркви) и королю везде, где бы ни отказывались уплачивать законные церковные подати, определяемые епископами.

Вертикальная связность текстов древнеанглийских международных договоров обеспечивается порядковыми числительными при перечислении пунктов договоров:

Arest ymb ure landzетюra... (Во-первых, о наших границах...).

Đet is ponon arest, peet hiz зесwøedon (Во-вторых (букв. «после первого»), они заявили...)

Употребление этой части речи способствует не только лучшему восприятию логики и последовательности информационных потоков в тексте, но и внутренней структуры текста, которая при отсутствии деления на абзацы никак иначе не маркируется.

\section{5 Тенденция к деперсонализованным способам изложения:}

\section{использование структур с неопределённо-личным местоимением man / mon}

Правовая норма предполагает абстрагирование от конкретных ситуаций. В тексте официальных документов это выражается в деперсонализации лексики и синтаксиса. В то время как одним из типичных признаков современного официально-делового стиля является употребление пассивного залога, особенностью древнеанглийского языка было частотное использование неопределённо-личного типа предложений с тем, чтобы придать отвлечённый характер тексту. Наиболее распространены были предложения с подлежащим, выраженным неопределённо-личным местоимением man / mon:

ealle we cweedon on ðam deeze ðe mon ða aðas swor

Все мы провозгласили в день, когда были принесены клятвы

Всего в сравнительно небольшом по объёму тексте рассматриваемых соглашений (около 1100 слов) зафиксировано 19 случаев употребления местоимения man / mon. В это число входят только те случаи, в которых данная форма употребляется как прономинолизованное средство выражения неопределённости агенса:

3if deapscyldiz man scriftsproece zyrne, ne him man nofre ne wyrne

если осуждённый на смерть иеловек желает исповедаться, ему никогда нельзя отказывать

В данном примере прономинальное неопределённо-личное значение выражается формой тап только во втором случае, где она служит целям абстрагирования правовой нормы от конкретной ситуации. В первом же случае форма тап определяется прилагательным deapscyldiz (ocyждённый на смерть) и выступает как полноценное существительное с лексическим значением человек.

\section{6. Сложность синтаксических конструкций}

Одним из важных признаков текста официальных документов является синтаксическая осложнённость, выражающаяся, как правило, в частотном употреблении сложных предложений. В тексте изучаемых соглашений из 49 предложений различной, но в основном высокой степени распространённости только 12 являются простыми.

В рассматриваемых соглашениях сложные предложения демонстрируют преобладание подчинительных отношений. Наиболее характерным надо признать использование сложноподчинённых предложений с условными придаточными:

3if man zehadodne oððе alðеodizne purh eniz ðinz forraede at feo oððe aet feore, ponne sceal him cyn3

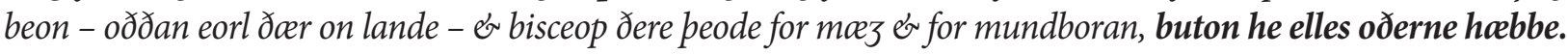


Если кто как-либо покусится на собственность или жизнь человека в священном сане или чужеземиа, то должен король или олдермен той земли и епископ той епархии действовать как сородичи и защитники пострадавщего, если у того нет иных.

В данном случае в составе сложноподчинённого предложения использованы два условных придаточных с союзами зif и buton. Сложные синтаксические структуры придают текстам международных договоров формальный характер.

Несколько реже встречаются придаточные предложения дополнения и уступки, а также придаточные относительные:

se ðe paet abrece, zylde lahslit mid Denum, wite mid Enzlum

тот, кто это нарушит, пусть заплатит лахслит у данов и фиксированньй итраф у англосаксов

\section{7. Стремление к языковой экономии}

Языковая экономия - основополагающий принцип функционирования языка, который основывается на стремлении достичь наибольшего результата наименьшим количеством средств и реализуется на всех уровнях языка и во всех стилях. Официально-деловой стиль, к которому относятся рассматриваемые нами тексты международных договоров, здесь не является исключением. Уже первые исследования принципа языковой экономии показали,что он обнаруживался уже на ранних этапах развития языка [14]. Как отмечается, основными средствами достижения языковой экономии среди прочих являются сложные слова, аббревеатуры, сокращения, эллиптические конструкции, неполные предложения [1]. Несмотря на то, что аббревеатуры и сокращения появляются ещё в Древнем Риме, в древнеанглийских международных документах они не встречаются, что, скорее всего, связано со стремлением достичь максимальной ясности текста и избежать неточностей в его толковании. На лексическом уровне принцип языковой экономии реализуется прежде всего за счёт морфологически сложных слов (дефисы далее показывают раздел морфем): hand-зrið (безопасность), а-зyld-е (без компенсации), land-ze-тюr-е (граници), зе-stæl-an (вменять), deap-scyld-із (приговорённый к смерти) и др.

На синтаксическом уровне языковая экономия достигается путём употребления простых неполных предложений, используемых как названия разделов: Be ordele \& apum (O (cyдебных) пытках и клятвах); Ве зеtутит (О поручителях), Ве sibleзеrит (О кровосмесительном прелюбодеянии). Эти синтаксические единицы выполняют основные функции заголовков - обобщение и компрессия информации.

\section{3. Выводы}

Исследование показало, что основные лингвостилистические черты международных договоров - это стереотипность лексико-грамматического оформления, стандартизация членения и композиции, синтаксический параллелизм условных периодов, связность на основе лексических повторов, вводных слов, тенденция к деперсонализованным способам изложения, сложность синтаксических конструкций, стремление к языковой экономии сложились ещё в древнеанглийский период. Особенностями первых международных соглашений по сравнению с современными являются: отсутствие заключения в композиционной структуре, синтаксический праллелизм условных периодов как основа членения текста, широкое применение неопределённо-личных структур с местоимением man / mon, отсутствие аббревиатур как средства языковой экономии, образный характер отдельных клишированных единиц. Таким образом, на основе сохранившегося материала безотносительно к развитию лексико-грамматической структуры английского языка можно предположить, что международные договоры как тип текста в ходе своего исторического становления и развития претерпели некоторые лингвостилистические изменения, которые, однако, нельзя признать радикальными.

(C) Мухин С.В., Ефремова Д.А., 2020 


\section{Список литературы}

1. Адмони В. Г. Основы теории грамматики. М.: Едиториал УРСС: УРСС, 2004. 103 с.

2. Алонцева О. А. Лингвистическое основы обучения студентов-юристов составлению официально-деловых документов // Вестник РУДН. Сер. Вопросы образования: языки и специальность. 2008. № 2. С. 76-81.

3. Баландина Л. А. Язык дипломатии: традиции и современность / Л.А. Баландина, Г.Ф. Кураченкова // Язык и право: актуальные проблемы взаимодействия: материалы Междунарондной научно-практической Интернет-конференции. Ростов-на-Дону: Ростовское книжное издательство, 2011. С. 6-16.

4. Борисова Л.А. Основные требования к тексту закона и их соблюдение при переводе // Вестник ВГУ. Сер.: Лингвистика и межкультурная коммуникация. 2008. № 1. С. 66-71.

5. Дипломатический словарь / Гл. ред. А. Я. Вышинский и С. А. Лозовский. В 2-х т. М.: Гос. изд-во полит. лит., 1948.1851 с.

6. Кафтя А. И. Сравнительный анализ конституционного и дипломатического дискурсов // Филологические науки. Вопросы теории и практики. Тамбов: Грамота, 2017. № 1 (67): в 2-х ч. Ч. 1. С. 126-128.

7. Ковалев Л.Н. Военно-политический договор как тип текста: Дис. ... канд. филол. наук. М., 2000. 208 с.

8. Ковалевская Е. Г. История русского литературного языка. М.: Просвещение, 1978. 384 с.

9. Крюкова Е.А. Язык и стиль законодательных актов: Дис. ... канд. юрид. наук. М., 2003. 139 с.

10. Кунин А. В. Большой Англо-русский фразеологический словарь. М.: Живой язык, 1998. 942 с.

11. Логунова К. А. Структурные особенности дипломатических документов // Филологические науки. Вопросы теории и практики. Тамбов: Грамота, 2015. № 2. Ч. 2. С. 129-132.

12. Лященко Б. И. Синтаксико-стилистическая структура текстов советских дипломатических документов (на материале политических договоров и коммюнике): Дис. ... канд. филол. наук. Киев, 1978. 188 с.

13. Максимов С. Е. Прагматические и структурно-семантические особенности текста международного договора (на материале английского языка): Дис. ... канд. филол. наук. Киев, 1984. 199 с.

14. Мартине А. Механизмы фонетических изменений: проблемы диахронической фонологии. М. : КомКнига, 2006.261 с.

15. Мухин С. В. История английского языка. Enzliscre Spræce Stær. Historie of the Englishe Tonge. History of the English Language / С.В. Мухин, Е.Б. Морозова. М.: ЛЕНАНД, 2020. 264 с.

16. Носик С. Г. Становление и развитие официально-делового стиля в английском языке (на материале древнеанглийского языка): Автореф. дис. .... канд. филол. наук. Киев, 1975. 24 с.

17. Ошурмахмадова С. Ш. Особенности лексики дипломатического делопроизводства // Мир науки, культуры, образования. 2019. № 1 (74). С. 475-476.

18. Пиглоткин А. С. Язык закона. М.: Юридическая литература, 1990. 192 с.

19. Руберт И. Б. Становление и развитие английских регулятивных текстов (структурные, семантические, прагматические аспекты): Автореф. дис. ... д-ра филол. наук. СПб., 1996. 46 с.

20. Рябкова И. П. Лингвоструктурные особенности договора в российском, американском и британском праве: сопоставительно-переводческий аспект / И.П. Рябкова, А.Н. Кожевникова // Многоязычие в образовательном пространстве. 2018. № 10. С. 140-148.

21. Сейфулина Н. А. Текстообразующая функция сложно-подчинённых предложений в тексте законов // Вестник Ставропольского государственного университета. 2009. № 60. С. 128-133.

22. Attenborough F. L. The Laws of the Earliest English Kings. Cambridge, 1922. 256 p.

23. Cambridge, Corpus Christi College, MS 383: Anglo-Saxon Laws [Электронный pecypc]. URL: https://parker.stanford.edu/ parker/catalog/mv340ty8592 (дата обращения: 05.04.2020).

24. Chaney W. A. The Cult of Kingship in Anglo-Saxon England. The Transition from Paganism to Christianity. Manchester, 1970. $276 \mathrm{p}$.

25. Galperin I. R. English Stylistics. Moscow: URSS, 2017. 332 p.

26. Goodrich P. Legal Discourse: Studies in Linguistics, Rhetoric and Legal Analysis. N.Y.: St. Martin’s Press, 1987. 266 p.

27. Murici M. The Language of the Law - Some Characteristics // International Journal of English Language, Literature and Translation Studies. India, 2017. Vol.4. Issue 1. P. 66-69.

28. Stenton F. M. Anglo-Saxon England. Oxford University Press, 2001. 812 p.

29. Wergild. Dictionary.com [Электронный pecypc]. URL: https://www.dictionary.com/browse/weregild (дата обращения: 10.04.2020).

30. Manuscript A: The Parker Chronicle. The Anglo-Saxon Chronicle: An Electronic Edition (Vol. 1). Literary edition [Электронный ресурc]. URL: http://asc.jebbo.co.uk/a/a-L.html (дата обращения: 13.04.2020).

\section{References}

1. Admoni, V. G. Osnovy teorii grammatiki [Essentials of Grammar Theory]. M.: Editorial URSS: URSS, 2004. 103 p.

2. Alontseva, O. A. Lingvisticheskie osnovy obucheniia studentov-iuristov sostavleniiu ofitsial'no-delovykh dokumentov [Linguistic Essentials of Teaching Law Students to Make Official Documents] // Vestnik RUDN. Ser. Voprosy obrazovaniia: iazyki i spetsial'nost'. 2008. № 2. P. 76-81.

3. Balandina, L. A., Kurachenkova G. F. Iazyk diplomatii: traditsii i sovremennost' [Dimplomacy Language: Traditions Today] // Iazyk i pravo: aktual'nye problemy vzaimodeistviia: materialy Mezhdunarondnoi nauchno-prakticheskoi Internet-konferentsii. Rostov-na-Donu: Rostovskoe knizhnoe izdatel'stvo, 2011. P. 6-16.

4. Borisova, L. A. Osnovnye trebovaniia k tekstu zakona i ikh sobliudenie pri perevode [Main Requirements of Legal Text: What is to Observe in Translation] // Vestnik VGU, ser: Lingvistika i mezhkulturnaia kommunikatsiia. 2008. №1. P. 66-71. 
5. Diplomaticheskii slovar' [Dictionary of Diplomacy] / Gl. red. A. Ia. Vyshinskii i S. A. Lozovskii. V 2-kh t. M.: Gos. izd-vo polit. lit., 1948. $1851 \mathrm{p}$.

6. Kaftia, A. I. Sravnitel'ny analiz konstitutsionnogo i diplomaticheskogo diskursov [Comparative Analysis of Constitutional and Diplomatic Discourses] // Filologicheskie nauki. Voprosy teorii i praktiki. Tambov: Gramota, 2017. № 1 (67): in 2 parts. Part I. P. $126-128$.

7. Kovalev, L.N. Voenno-politicheskii dogovor kak tip teksta [War and Politics Treaty as a Text Type]: Dis. ... kand. filol. nauk. M., 2000. 208 p.

8. Kovalevskaia, E. G. Istoriia russkogo literaturnogo iazyka [History of Literary Russian]. M.: Prosveshchenie, 1978. 384 p.

9. Kriukova, E.A. Iazyk i stil' zakonodatel'nykh aktov [Language and Style of Legislation]: Dis. ... kand. iurid. nauk. M., 2003.139 p.

10. Kunin, A.V. Bol'shoi Anglo-russkii frazeologicheskii slovar' [English-Russian Phraseological Dictionary]. M.: Zhivoi iazyk, 1998. $942 \mathrm{p}$.

11. Logunova, K. A. Strukturnye osobennosti diplomaticheskikh dokumentov [Structural features of Diplomatic Papers] // Filologicheskie nauki. Voprosy teorii i praktiki. Tambov: Gramota, 2015. № 2. Ch. 2. P. 129-132.

12. Liashchenko, B. I. Sintaksiko-stilisticheskaia struktura tekstov sovetskikh diplomaticheskikh dokumentov (na materiale politicheskikh dogovorov i kommiunike) [Syntax and Style of the Structure of Soviet Diplomatic Papers (Exemplified by Political Treaties and Communiques)]: Dis. ... kand. filol. nauk. Kiev, 1978. 188 p.

13. Maksimov, S. E. Pragmaticheskie i strukturno-semanticheskie osobennosti teksta mezhdunarodnogo dogovora (na materiale angliiskogo iazyka) [Pragmatic and Structural-Semantic features of International Agreements]: Dis. ... kand. filol. nauk. Kiev, 1984. $199 \mathrm{p}$.

14. Martine, A. Mekhanizmy foneticheskikh izmenenii: problemy diakhronicheskoi fonologii [Mechanisms of Phonetic Change: Problems of Diachronic Phonology]. M.: KomKniga, 2006. 261 p.

15. Mukhin, S. V., Morozova E. B. Istoriia angliiskogo iazyka. Enzliscre Spreece Ster. Historie of the Englishe Tonge. History of the English Language. M.: LENAND, 2020. 264 p.

16. Nosik, S. G. Stanovlenie i razvitie ofitsial'no-delovogo stilia $v$ angliiskom iazyke (na materiale drevneangliiskogo iazyka) [Rise and Evolution of Official Style in English (Exemplified by Old English Linguistic Evidence]: Avtoref. dis. .... kand. filol. nauk. Kiev, 1975. $24 \mathrm{p}$.

17. Oshurmahmadova, S. Sh. Osobennosti leksiki diplomaticheskogo deloproizvodstva [Peculiarities of the Vocabulary of Diplomatic Documentation] // Mir nauki, kul'tury, obrazovanija. 2019. \# 1 (74). P. 475-476.

18. Piglotkin, A. S. Iazyk zakona [Language of Law]. M.: Iuridicheskaia literatura, 1990. 192 p.

19. Rubert, I. B. Stanovlenie i razvitie angliiskikh reguliativnykh tekstov (strukturnye, semanticheskie, pragmaticheskie aspekty) [Rise and Evolution of English Regulatory Texts (Structure, Semantics, Pragmatics)]: Avtoref. dis. ... d-ra filol. nauk. SPb., 1996. 46 p.

20. Riabkova, I. P., Kozhevnikova A. N. Lingvostrukturnye osobennosti dogovora v rossiiskom, amerikanskom i britanskom prave: sopostavitel'no-perevodcheskii aspekt [Linguostructural Features of Treaties in Russian, American and British Legislation: Comparative and Translation Aspects] // Mnogoiazychie v obrazovatel'nom prostranstve. 2018. № 10. P. 140-148.

21. Seifulina, N. A. Tekstoobrazuiushchaia funktsiia slozhno-podchinennykh predlozhenii v tekste zakonov [Complex Sentences in Legislation in Text Making] // Vestnik Stavropol'skogo gosudarstvennogo universiteta. 2009. № 60. P. 128-133.

22. Attenborough, F. L. The Laws of the Earliest English Kings. Cambridge, 1922. 256 p.

23. Cambridge, Corpus Christi College, MS 383: Anglo-Saxon Laws [Online], parker.stanford.edu/parker/catalog/mv340ty8592 (accessed: 05 April 2020).

24. Chaney, W. A. The Cult of Kingship in Anglo-Saxon England. The Transition from Paganism to Christianity. Manchester, 1970. $276 \mathrm{p}$.

25. Galperin, I. R. English Stylistics. Moscow: URSS, 2017. 332 p.

26. Goodrich, P. Legal Discourse: Studies in linguistics, rhetoric and legal Analysis. N.Y.: St. Martin’s Press, 1987. 266 p.

27. Murici, M. The Language of the Law - Some Characteristics // International Journal of English Language, Literature and Translation Studies. India, 2017. Vol.4. Issue 1. P. 66-69.

28. Stenton, F. M. Anglo-Saxon England. Oxford University Press, 2001. 812 p.

29. Wergild. Dictionary.com [Online], www.dictionary.com/browse/weregild (accessed: 10 April 2020).

30. Manuscript A: The Parker Chronicle. The Anglo-Saxon Chronicle: An Electronic Edition (Vol. 1). Literary edition [Online], asc. jebbo.co.uk/a/a-L.html (accessed: 13 April 2020).

\section{Сведения об авторах:}

Мухин Сергей Владимирович - кандидат филологических наук, доцент кафедры английского языка № 1 МГИМО (Россия, Москва). Сфера научных и профессиональных интересов: языковые контакты в области фразеологии, германистика, история английского языка.

E-mail: s.muhin@inno.mgimo.ru

Ефремова Дарья Андреевна - кандидат филологических наук, преподаватель кафедры английского языка № 1 МГИМО (Россия, Москва). Сфера научных и профессиональных интересов: стилистика текста, биографический жанр, история английского языка.

E-mail: efremovadarya@yandex.ru

Конфликт интересов: Авторы заявляют об отсутствии конфликта интересов. 


\section{About the authors:}

Sergey V. Mukhin - PhD, Assistant Professor of English Language Department №1, MGIMO University (Moscow, Russia). Spheres of research and professional interest: linguistic contacts in phraseology, Germanic studies, history of English.

E-mail: s.muhin@inno.mgimo.ru

Ефремова Дарья Андреевна - PhD, Lecturer of English Language Department №1, MGIMO University (Moscow, Russia). Spheres of research and professional interest: text stylistics, biographic genre, history of English.

E-mail: efremovadarya@yandex.ru

Conflicts of interest: The authors declare absences of conflicts of interest. 